\title{
MULTIPLE DAMAGE OF THE TIBIAL POLYETHYLENE INSERT IN KNEE JOINT PROSTHESIS (CAN EXCELLENT POSTOPERATIVE OUTCOME BE THE CAUSE OF THE TIBIAL INSERT FRACTURE?) Case report and review
}

\author{
Eun-Kyoo Song ${ }^{1}$, Kamolhuja Eshnazarov ${ }^{2}$, Saodat Asilova ${ }^{3}$, Jong-Keun Seon ${ }^{1}$ \\ ${ }^{1}$ Department of Orthopaedic Surgery, Chonnam National University Hwasun Hospital, Seoul, Korea \\ ${ }^{2}$ Department of Orthopaedic Surgery, Shinchon Yonsei Hospital, Seoul, Korea \\ ${ }^{3}$ Department of Traumatology, Orthopedics and Neurosurgery, Tashkent Medical Academy, Tashkent, Uzbekistan
}

\begin{abstract}
Despite improvements in prosthesis technology and use of high-quality materials in recent years, the number of revisions related to implant failures (4.7\%) remains high. Several phenomena were reported in literature as reasons for dislocation and fracture of tibial insert in mobile bearing prosthesis: incorrect positioning of components, discrepancy of extension and flexion balancing or ligament weakness. However, in our cases neither of these causes were observed. The authors consider that bio-physiological and biomechanical aspects of total knee arthroplasty and knee joint prosthesis should be thoroughly studied and implemented into the clinical practice. In the described cases, multiple damage of the insert due to flexion instability and "twist-hyperflexion" in overweight patients is perceived as the reason for failures.
\end{abstract}

Key words: total knee arthroplasty, mobile-bearing, floating platform prosthesis, tibial insert failure.

\section{Introduction}

The rapid proliferation of total knee arthroplasty naturally increases the number of complications and revision cases [2, 4]. Despite improvements in prosthesis technology and the use of high-quality materials, the number of revisions related to implant failures $(4.7 \%)$ remains high $[1,3]$ throughout the recent years. Reports have been made citing deformation, early wear, delamination, decomposition of the backside or border part of the polyethylene insert and damage of the tibial post in knee joint prosthesis $[9,11,19]$. However, multiple complicated failures with complete fracture of posterior flexion part of the tibial insert were very rare. In our practice we observed only two such cases with interesting arthroplasty history resulting in failure.

\section{Case 1}

A 65 year old woman (weight $=58 \mathrm{~kg}$, height $=$ $1.43 \mathrm{~m}$, body mass index $=28.4$ ) sought help from our hospital regarding pain in the left knee joint persisting for the past six months. Eleven years ago she underwent a high tibial osteotomy on the right knee due to medial unicompartmental osteoarthritis (OA); in five years after that total knee arthroplasty was performed on her left knee using a floating platform mobile-bearing TKA with a $10 \mathrm{~mm}$ polyethylene insert (e.motion ${ }^{\circledR} \mathrm{FP}$, B. Braun-Aesculap). However, five years after the surgery she felt instability and pain in her left knee when standing up from a seated position. Physical examination of the knee showed the range of motion from $20^{\circ}$ to $110^{\circ}$; there was a clicking sound and pain in full flexion. Further tests showed medial joint line tenderness $(-)$, valgus/varus stress test $(-/+)$ (Fig. 1), locking/crepitus $(-/+), C R P$ value of 0.81 . She felt the first crunch in the knee while she wanted to raise hergranddaughter on her back when sitting with full flexed knee.

Through the previous skin incision a medial parapatellar arthrotomy was performed to remove damaged insert. Intraoperative findings showed that the lateral posterior flexion part of the tibial polyethylene insert was fractured and displaced to the rear part of the knee.

Additionally, authors observed destruction of the posterior edge of the broken fragment and posteromedial part of the upper surface of the tibial insert known as "melting" (Fig. 2). After irrigation of the knee joint and surrounding soft tissues with aseptic solution the tibial insert was replaced. Postoperatively the range of motion was observed

Cite as: Eun-Kyoo Song, Kamolhuja Eshnazarov, Saodat Asilova, Jong-Keun Seon. Multiple damage of the tibial polyethylene insert in knee joint prosthesis (Can excellent postoperative outcome be the cause of the tibial insert fracture?). Case report and review. Travmatologiya i ortopediya Rossii. 2016; (1):124-128.

$\triangle$ Eshnazarov Kamolhuja Eshnazarovich. Seoul, Korea; e-mail: kamolhuja77@mail.ru

11 Received: 20.01.2015; Accepted for publication: 17.02.2016 
from $0^{\circ}$ to $130^{\circ}$ of flexion. The patient was discharged four days after surgery following medical treatment and physiotherapy.
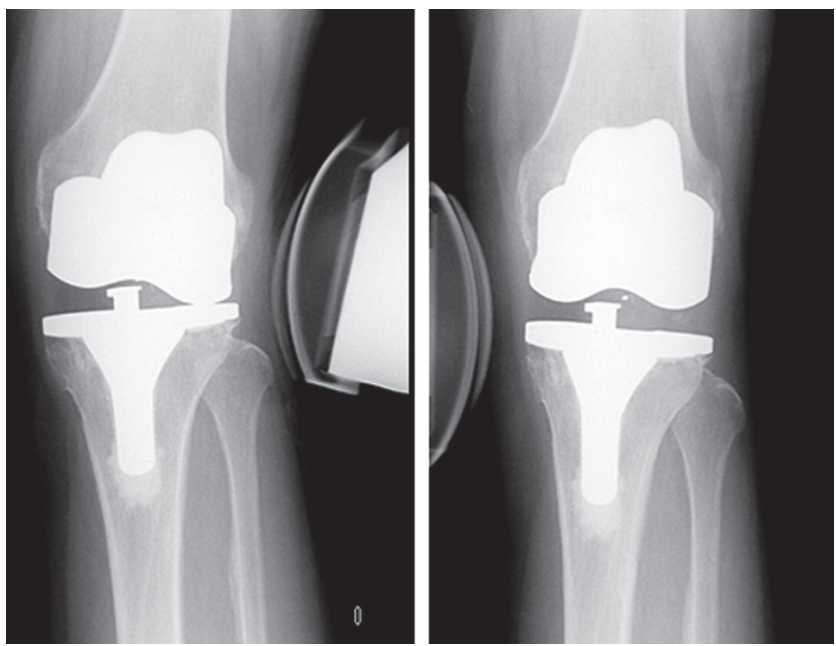

Fig. 1. Stress test with lateral femorotibial subluxation
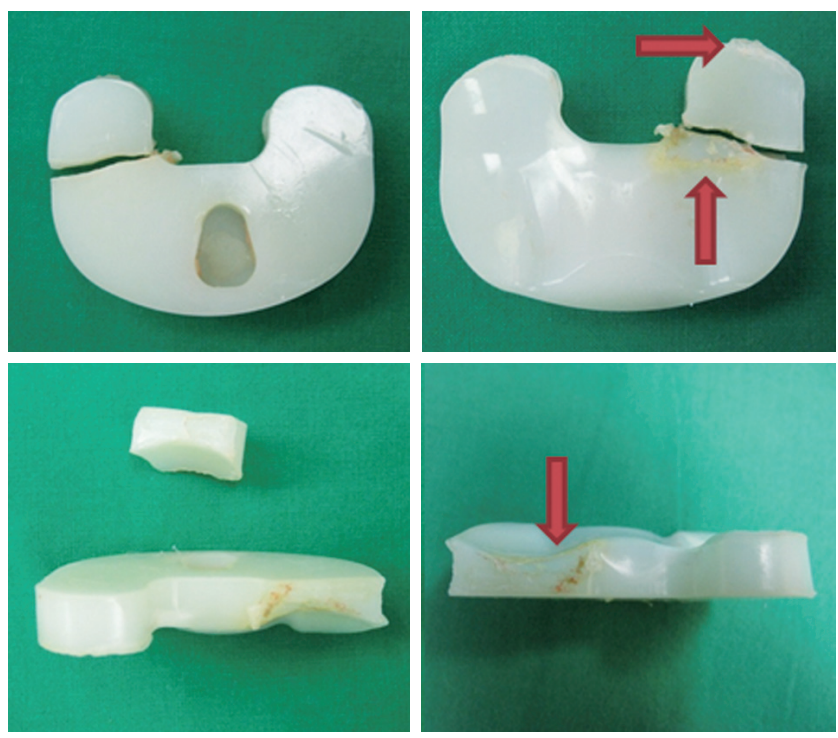

Fig. 2. Destruction of the tibial polyethylene insert as «Melting»

\section{Case 2}

A 59 year old woman (body mass index $=26.7$ ) complained of the right knee pain during previous two weeks. Eight years ago the patient was arthroscopically diagnosed with a Baker's cyst, and subsequently underwent an open cystectomy in a private hospital. Three years ago she underwent a computer navigated TKA (using a floating platform mobile bearing prosthesis with a $10 \mathrm{~mm}$ thick polyethylene bearing (e.motion ${ }^{\circledR}$ FP, B. Braun-Aesculap) in our hospital due to OA in the right knee.
She felt a sudden onset, sharp pain in her right knee while walking downstairs. No swelling or knee motion limitation was reported at the time. The range of motion during right knee examination was observed from $0^{\circ}$ to $130^{\circ}$; there was clicking sound and pain during full flexion. Further tests showed patellar tendon tenderness $(+)$, valgus/varus stress test $(+/+)$, locking/crepitus $(+/+)$, CRP value of 0,83 . Radiographs showed reduction in the distance between the femoral and tibial components (Figure 3 ). The patient associates pain with a daily routine sitting position while working on a kale farm, pain onset she noticed a month ago when trying to lift heavy goods from a seated position with flexed knee.
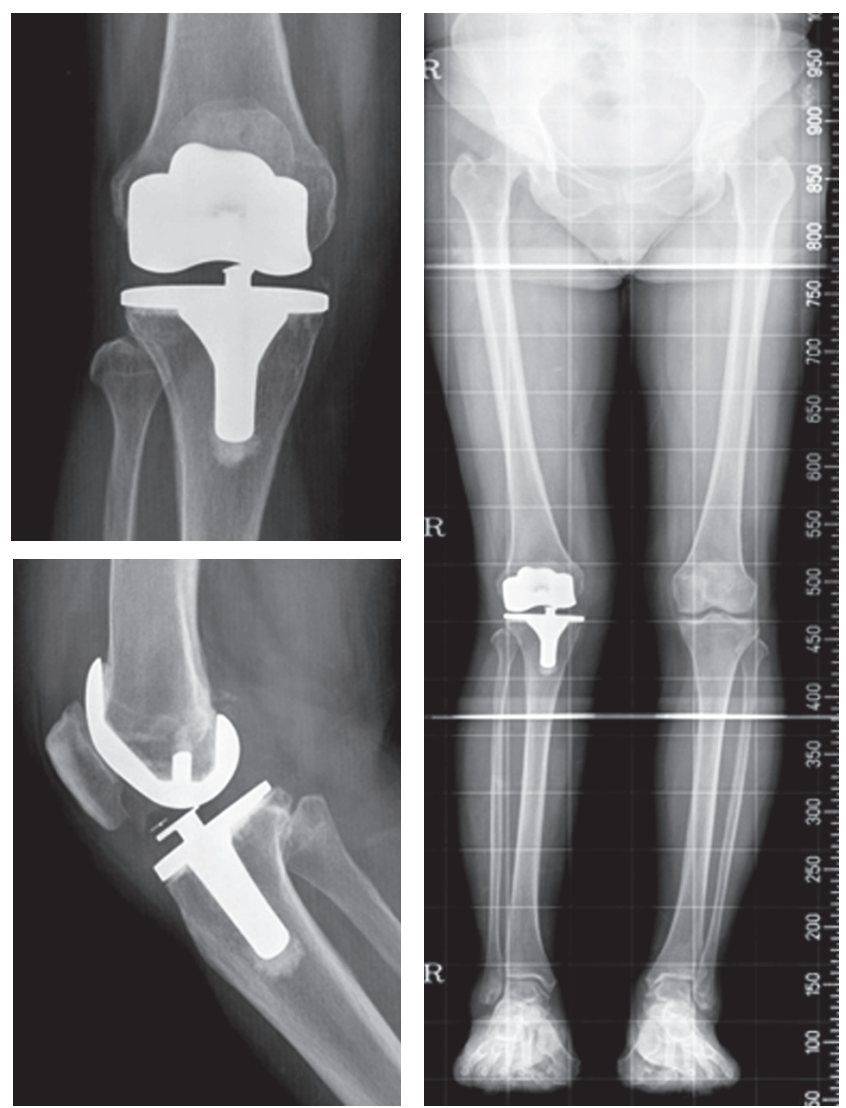

Fig. 3. Radiographs before revision damaged prosthesis

Revision TKA was performed using a standard mid-line incision and medial parapatellar arthrotomy. Intraoperative findings showed that the lateral posterior flexion part of the tibial polyethylene insert was fractured and a broken fragment was displaced towards the anterior part of the knee. In addition, the anterior segment of the backside of the tibial polyethylene insert was broken off and freely moving within the joint. The displaced insert changed its position during flexion and extension (Fig. 4). 

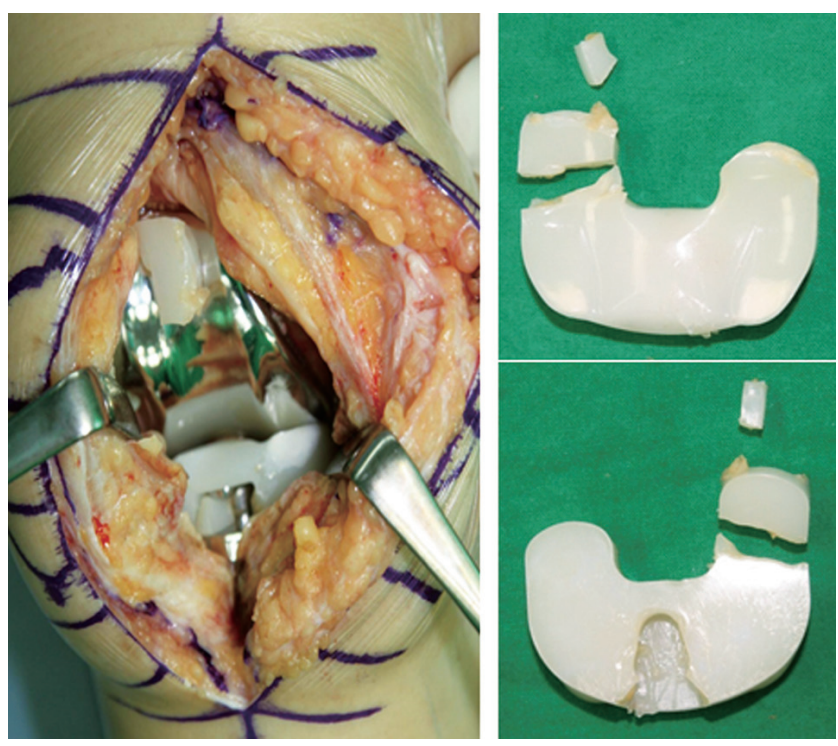

Fig. 4. Multiple fractures of the tibial polyethylene insert

After removing polyethylene remnants and performing irrigation the tibial insert was replaced. Postoperatively, range of motion was from $5^{\circ}$ to $125^{\circ}$ of flexion. After a routine postoperative therapy the patient was relieved and discharged from the hospital.

\section{Discussion}

Analysis of 391.913 primary TKAs showed that $36.307(9.3 \%)$ revisions were performed due to loosening, infection, periprosthetic fractures and other reasons, among those revisions due to implant failures rates $0.44 \%$ [20]. Other authors reported revision rates related to implant failure in range from 0,073 to $0.94 \%[7,15,18]$.

Several researchers reported excellent postoperative TKA outcomes using mobile bearing e.motion ${ }^{\circledR}$ floating platform with a cruciate retaining design $[5,10,13]$. They believe that limitation of the platform movement during the flexion, extension and rotation prevents dislocations and early failure of the insert. However, our studies showed some cases $[17,24]$ where theoretically an increase in tibial insert failures should have been expected. Therefore, authors consider it not sufficient to rely only on kinematic limitations in clinical practice.

Several phenomena were described in literature as reasons for dislocation of the tibial insert in mobile bearing prosthesis: impingement of the insert with osteophyte or soft tissues during activities, incorrect positioning of prosthesis components, discrepancy of extension and flexion balance or ligaments weakness [8, 13, 22]. However, neither clinical examinations nor intra-operative findings revealed above as possible reasons for dislocation.
Only a similar mechanism of crepitus onset allows us to suppose that such fractures must evolve due to "twist-hyperflexion" in overweight patients. H. Shimagaki et al affirmed that the hyperflexion of TKA leads to a progression of a downward strength on the posterior half of the tibia polyethylene insert [21,23] and the authors consider that in such circumstances the increase in action force and simultaneous movement of the rotation axis may result in overloading of certain parts of the insert. Finally, misbalancing of the action force can lead to fracture of tibial insert with or without dislocation. At the same time this angular friction could be a reason for damage of the posterior side of the insert before breakage, and after displacement of a broken fragment the full incongruence of the component surface and constant knee motion can lead to a damage of the tibial polyethylene insert known as «melting» (Fig. 2). Actually, the opinions and conclusions of many authors create a certain paradox where a satisfactory range of motion almost identical to physiological norm without restriction is considered to be an excellent result $[10,23]$, when namely good recovery of the knee joint motion leads to serious complications.

Despite multiple research, improvements in implants quality, surgical technique and clinical outcomes [6,14,16], based on own practical experience and some case reports contributed by other researchers [12, 19, 24] the authors consider that bio-physiological and biomechanical aspects of total knee arthroplasty and knee joint prosthesis should be thoroughly studied and implemented into the clinical practice. In the described cases, multiple damage of the insert due to flexion instability and "twist-hyperflexion" in overweight patients is perceived as the reason for failures.

\section{Conflict of interest: none.}

\section{References / Литература}

1. Baker RP, Masri BA., Greidanus NV, Garbuz DS. Outcome after isolated polyethylene tibial insert exchange in revision total knee arthroplasty. J Arthroplasty. 2013; 28(1):1-6.

2. Bansal A, Khatib ON, Zuckerman JD. Revision total joint arthroplasty: the epidemiology of 63,140 cases in New York State. J Arthroplasty. 2014; 29(1):23-27.

3. Bozic KJ, Kurtz SM, Lau E et al. The epidemiology of revision total knee arthroplasty in the United States. Clin Orthop Relat Res. 2010; 468:45-51.

4. Culliford D, Maskell J, Judge A, Cooper C, PrietoAlhambra D, Arden N et al. Future projections of total hip and knee arthroplasty in the UK: results from the UK. Clinical Practice Research Datalink. Osteoarthritis Cartilage. 2015; 23:594-600.

5. Geiger F, Mau H, Krüger M et al. Comparison of a new mobile-bearing total knee prosthesis with a fixed-bearing prosthesis: a matched pair analysis. Arch Orthop Trauma Surg. 2008; 128:285. 
6. Gilbert SL, Rana AJ, Lipman JD, Wright TM, Westrich GH. Design changes improve contact patterns and articular surface damage in total knee arthroplasty. Knee. 2014; 21(6):1129-1134.

7. Gøthesen Ø, Espehaug B, Havelin L et al. Survival rates and causes of revision in cemented primary total knee replacement: a report from the Norwegian arthroplasty register 1994-2009. Bone Joint J. 2013; 95(5):636-642.

8. Hwang BH, Lee WS, Park KK et al. Anterior-posterior glide mobile-bearing total knee arthroplasty complications related to prosthesis design. J Arthroplasty. 2011; 26(8):1438-1444.

9. In Y, Sur YJ, Won HY, Moon YS. Recurrent dissociation of the tibial insert after mini-subvastus posterior-stabilized total knee arthroplasty: a case report. Knee. 2011; 18(6):461-463.

10. Kim TK, Chang CB, Kang YG, Chung BJ, Cho HJ, Seong SC. Early clinical outcomes of floating platform mobile bearing TKA: longitudinal comparison with fixed bearing TKA. Knee Surg Sports Traumatol Arthrosc. 2010; 18(7):879-882.

11. Kumar N, Yadav C, Raj R, Yadav S. Fracture of the polyethylene tibial post in a posterior stabilized knee prosthesis: A case report and review of literature. J Orthopaedics. 2015; 12(3):160-163.

12. Lee CS, Chen WM, Kou HC, Lo WH, Chen CL. Early nontraumatic fracture of the polyethylene tibial post in a NexGen LPS-Flex posterior stabilized knee prosthesis. J Arthroplasty. 2009; 24(8):1292-1292.

13. Lee DH, Lee DK, Shin YS, Han SB. Mid-term outcomes of floating platform mobile-bearing total knee arthroplasty under navigational guidance with a minimum 4-year follow-up.J Arthroplasty. 2013; 28(10):1801-1805.

14. Lockard CA, Sanders AP, Raeymaekers B. An experimental approach to determining fatigue crack size in polyethylene tibial inserts. J Mech Behavior Biomed Mater. 2015; 54:106-114.

15. Maas A, Kim TK, Miehlke RK, Hagen T, Grupp TM. Differences in anatomy and kinematics in Asian and
Caucasian TKA patients: influence on implant positioning and subsequent loading conditions in mobile bearing knees. BioMed Res Int. 2014, 2014; 2014:612838. doi: 10.1155/2014/612838.

16. Pruitt LA. Deformation, yielding, fracture and fatigue behavior of conventional and highly cross-linked ultra high molecular weight polyethylene. Biomaterials. 2005; 26:905-915.

17. Ridgeway S, Moskal JT. Early instability with mobilebearing total knee arthroplasty. A Series of 25 cases. J Arthroplasty. 2004; 19(6):686-693.

18. Robertsson O, Knutson K, Lewold S, Lidgren L. The Swedish Knee Arthroplasty Register 1975-1997: an update with special emphasis on 41,223 knees operated on in 1988-1997. Acta Orthop Scand. 2001; 72(5):503-513.

19. Rutten SGM, Janssen RPA. Spontaneous late dislocation of the high flexion tibial insert after Genesis II total knee arthroplasty. A case report. Knee. 2009; 16(5):409-411.

20. Sadoghi P, Liebensteiner M, Agreiter M. et al. Revision surgery after total joint arthroplasty: a complicationbased analysis using worldwide arthroplasty registers. J Arthroplasty. 2013; 28(8):1329-1332.

21. Shimagaki H, Bechtold JE, Sherman RE, Gustilo RB. Stability of initial fixation of the tibial component in cementless total knee arthroplasty. J Orthop Res. 1990; 8:64-71.

22. Thompson NW, Wilson DS, Cran GW, Beverland DE, Stiehl JB. Dislocation of the rotating platform after low contact stress total knee arthroplasty. Clin Orthop Relat Res. 2004; 1:207-211.

23. van Graan $\mathrm{W}$, van der Merwe $\mathrm{W}$. The influence of posterior condylar offset on maximum knee flexion: a retrospective analytical study. SA Orthop J. 2014; 13(1):65-68.

24. Yoon JR, Jeong HI, Oh KJ, Yang JH.Bilateral condyle fracture of tibial insert in mobile bearing total knee arthroplasty. Knee. 2014; 21(1):318-321.

\section{INFORMATION ABOUT AUTHORS:}

Eun-Kyoo Song - MD, PhD, Professor, Department of Orthopaedic Surgery, Chonnam National University, Hwasun Hospital, Seoul, Korea

Eshnazarov Kamolhuja E. - MD, Department of Orthopaedic Surgery, Shinchon Yonsei Hospital, Seoul, Korea

Asilova Saodat Ubaevna - MD, Professor, Department of Traumatology, Orthopedics and Neurosurgery Tashkent Medical Academy, Tashkent, Uzbekistan Korea

Jong Keun Seon - MD, PhD, Department of Orthopaedic Surgery, Chonnam National University, Hwasun Hospital, Seoul, 


\title{
МНОЖЕСТВЕННЫЕ ПОВРЕЖДЕНИЯ ПОЛИЭТИЛЕНОВОГО ВКЛАДЫША ЭНДОПРОТЕЗА КОЛЕННОГО СУСТАВА (МОЖЕТ ЛИ ОТЛИЧНЫЙ ФУНКЦИОНАЛЬНЫЙ ПОСЛЕОПЕРАЦИОННЫЙ РЕЗУЛЬТАТ СТАТЬ ПРИЧИНОЙ ПОВРЕЖДЕНИЯ ПОЛИЭТИЛЕНОВОГО ВКЛАДЫША?) Клинические наблюдения и обзор литературы
}

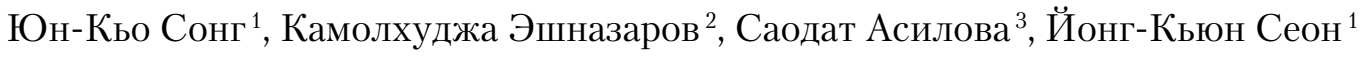 \\ ${ }^{1}$ Отделение ортопедической хирургии, Национальный университет Сhоппат, госпиталь Нталип, Сеул, Корея \\ ${ }^{2}$ Отделение ортопедической хирургии, Госпиталь Shinchon Yonsei, Сеул, Корея \\ ${ }^{3}$ Отделение травматологии, ортопедии и нейрохирургии, Ташкентская медииинская академия, \\ Ташкент, Узбекистан
}

\section{Реферат}

Несмотря на то, что в последние годы в производстве эндопротезов применяются усовершенствованные технологии и высококачественные материалы, число ревизионных вмешательств по причине несостоятельности имплантатов остается достаточно высоким $(4,7 \%)$. В научной литературе описываются несколько причин вывихов и повреждений полиэтиленового вкладыша конструкций эндопротезов коленного сустава с мобильной платформой, а именно: неправильное позиционирование компонентов, дисбаланс сгибательного и -разгибательного промежутков или несостоятельность связочного аппарата. Однако, в своей клинической практике авторы не наблюдали подтверждения подобных причин. По мнению авторов, необходимо тщательно исследовать и учитывать в клинической практике физиологические и биомеханические особенности как методики тотального замещения коленного сустава, так и самих имплантатов. В описываемых случаях в качестве причины неудовлетворительных исходов авторы отмечали множественные повреждения полиэтиленового вкладыша вследствие нестабильности при сгибании коленного сустава и/или глубокого сгибания в сочетании со скручивающим усилием у пациентов с избыточной массой тела.

Ключевые слова: тотальное эндопротезирование коленного сустава, эндопротез с подвижной платформой, повреждение полиэтиленового вкладыша.

Конфликт интересов: не заявлен.

\section{СВЕДЕНИЯ ОБ АВТОРАХ:}

Сонг Юн-Кьо - профессор, отделение ортопедической хирургии, Национальный университет Сhonnam, госпиталь Hwasun, Сеул, Корея

Эиназаров Камолхуджа - отделение ортопедической хирургии, клиника Shinchon Yonsei, Сеул, Корея

Асилова Саодат - отделение травматологии, ортопедии и нейрохирургии, Ташкентская медицинская академия, Ташкент, Узбекистан

Сеон Йонг-Кьюн - отделение ортопедической хирургии, Национальный университет Chonnam, госпиталь Нwasun, Сеул, Корея

О] Юн-Кьо Сонг, Камолхуджа Эшназаров, Саодат Асилова, Йонг-Кьюн Сеон. Множественные повреждения полиэтиленового вкладыша эндопротеза коленного сустава (Может ли отличный функциональный послеоперационный результат стать причиной повреждения полиэтиленового вкладыша?). Клинические наблюдения и обзор литературы. Травматология и ортопедия России. 2016; (1): 124-128.

$\triangle$ Эиназаров Камолхуджа. Сеул, Корея; e-mail: kamolhuja77@mail.ru

11 Рукопись поступила: 20.01.2015; принята в печать: 17.02.2016 